\title{
Improvement of myrosinase activity of Aspergillus sp. NR4617 by chemical mutagenesis
}

\author{
Nuansri Rakariyatham \\ Department of Chemistry, Faculty of Science \\ Chiang Mai University, Chiang Mai \\ 50200, Thailand \\ Tel: 6653943342 \\ Fax: 6653892277 \\ E-mail: nuansri1@yahoo.com \\ Bordin Butr-Indr* \\ Division of Clinical Microbiology \\ Department of Medical Technology \\ Faculty of Associated Medical Science \\ Chiang Mai University, Thailand \\ Tel: 6615950578 \\ Fax: 6653406294 \\ E-mail: royter99@hotmail.com \\ Hataichanoke Niamsup \\ Department of Chemistry, Faculty of Science \\ Chiang Mai University, Chiang Mai \\ 50200, Thailand \\ Tel: 6653943342 \\ Fax: 6653892277 \\ E-mail: Hatahichanok@hotmail.com \\ Lalida Shank \\ Department of Chemistry, Faculty of Science \\ Chiang Mai University, Chiang Mai \\ 50200 , Thailand \\ Tel: 6653943342 \\ Fax: 6653892277 \\ E-mail: Lalidashank@yahoo.com
}

Keywords: allylisothiocyanate, Aspergillus sp., $\beta$-thioglucosidase, myrosinase, EMS mutagenesis, MNNG mutagenesis.

Abbreviations: AIT: application in allylisothiocyanate
EMS: ethyl methanesulfonate
MNNG: N-methyl-N'-nitro-N-nitrosoguanidine

A myrosinase (thioglucoside glucohydrolase or thioglucosidase, EC 3.2.3.147) producing fungus, Aspergillus sp. NR4617, was newly isolated from decayed soil sample obtained in Thailand and was subjected to single exposure to two chemical mutagens, ethyl methanesulfonate (EMS) and N-methyl-N'-nitroN-nitrosoguanidine (MNNG). Its myrosinase production was selected on low cost medium prepared from mustard seed cake (Brassica juncea). Studies of production and stability of the enzyme showed that EMS mutagenesis increased myrosinase activity. Aspergillus sp. NR4617E1 produced myrosinase $1.90 \mathrm{U}$ $\mathrm{ml}^{-1}$ at $36 \mathrm{hrs}$ of the cultivation equivalent to $171 \%$ of the enzyme production in wild-type. The stability studies revealed that myrosinase from the mutant strains retained activity similar to wild-type at $30^{\circ} \mathrm{C}$. Aspergillus sp. NR4617E1 degraded $10 \mathrm{mM}$ of glucosinolate completely in 36 hrs. Enhanced myrosinase production and high yields of products (allylisothiocyanate) demonstrated that this mutant could be a new found candidate for feed detoxification and industrial allylisothiocyanate production.

Myrosinase (thioglucoside glucohydrolase EC 3.2.3.147) is found in all glucosinolate containing plants such as Brassicaseae (o Brassicaceae) in some bacteria and fungi (Rask et al. 2000). Myrosinase is normally segregated from glucosinolates, sugar anionic thioesters containing betathioglucolate glycoside bonds, in plant tissues (Brown and

* Corresponding author 
Morra, 1996). When plant cells are damaged or decomposed, myrosinase is released and catalyzes the hydrolysis of glucosinolates. The products of glucosinolate hydrolysis include glucose, sulphate, and a number of active allelochemicals such as isothiocyanates, nitriles, thiocyanates, cyanides, and others depending on substrates and reaction conditions used (Gil and Macleod, 1980). These allelochemicals have been found to inhibit weed seed germination and some pathogens in soil. Recently, several studies have proposed the use of glucosinolate containing plants as a cover crop to reduce the use of synthetic pesticides (Boydston and Hang, 1995; Yenish et al. 1996). Glucosinolates are useful, not only for their activity against bacteria, fungi, nematodes, tumour cell growth and in cancer prevention (Fenwick et al. 1983; Lazzeri et al. 1993; Leoni et al. 1997) but also their potential to be used as intermediates in chemical synthesis (Gueyrard et al. 2000).

Glucosinolates alone are not biologically active but their hydrolysis products by myrosinase are capable of suppressing seeds and pathogens (Brabban and Edwards, 1995). Myrosinase is, thus, the key enzyme for allelochemical production derived from glucosinolates.

Table 1. Matrix of the factorial $2^{3}$ planning.

\begin{tabular}{|c|c|c|c|}
\hline Experiments & $\boldsymbol{X}_{\mathbf{1}}$ & $\boldsymbol{X}_{\mathbf{2}}$ & $\boldsymbol{X}_{\mathbf{3}}$ \\
\hline 1 & -1 & -1 & -1 \\
\hline 2 & +1 & -1 & -1 \\
\hline 3 & -1 & +1 & -1 \\
\hline 4 & +1 & +1 & -1 \\
\hline 5 & -1 & -1 & +1 \\
\hline 6 & +1 & -1 & +1 \\
\hline 7 & -1 & +1 & +1 \\
\hline 8 & +1 & +1 & +1 \\
\hline 9 & 0 & 0 & 0 \\
\hline 10 & 0 & 0 & 0 \\
\hline 11 & 0 & 0 & 0 \\
\hline
\end{tabular}

Myrosinase and glucosinolates are beneficial to human and animals and have been studied extensively. Several reports have described the isolation and characterization of myrosinase, especially from white mustard and oilseed rape. A significant amount of work has been put into the recent cloning of plant myrosinase genes (Xue et al. 1992). Over the past 40 years a number of microorganisms including bacteria and fungi have been reported for their glucosinolate-degradation properties. The study of myrosinase, therefore, is significant for both biological and biotechnological aspects of food and feed industries. Most works focused on characterization of glucosinolate degradation by intact microbial cells (Maheshwari et al. 1981; Smiths et al. 1993; Palop et al. 1995; Rakariyatham and Sakorn, 2002) and several reports were published describing the selection of Aspergillus sp. for myrosinase production (Smiths et al. 1993; Sakorn et al. 1999).

Our laboratory has been interested in studying myrosinase from Aspergillus sp. in many aspects including biodegradation in liquid and solid culture (Sakorn et al. 1999; Rakariyatham and Sakorn, 2002), and new techniques for detectionof microorganisms that produce myrosinase by using sinigrin-bariumagar plate (Sakorn et al. 2002). Investigationson chemical mutagenesis of strains of Aspergillus sp. to improvemyrosinase production were our next step in myrosinase studies.In this work following microbial screening from soil we selected Aspergillus sp. NR4617 for its ability to produce intracellular myrosinase with high activity. We subsequently improved the enzyme activity of Aspergillus sp. NR4617 via chemical mutagenesis and selected the myrosinase improving mutants.

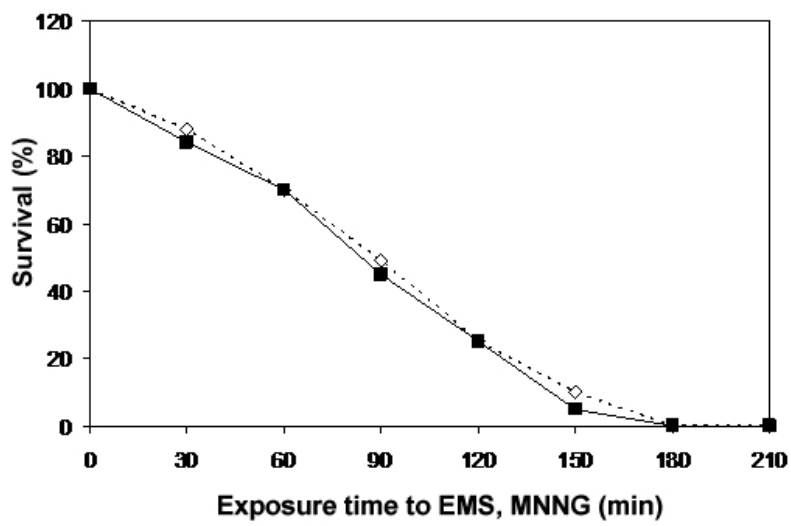

Figure 1. Survival curve of Aspergillus sp. NR4617 treat with EMS ( $\square$ ) and MNNG (ם). Each values represent means of three replicates test with SD error bars indicated.

\section{MATERIALS AND METHODS}

\section{Organism and media}

The wild-type strain Aspergillus sp. NR4617 was obtained from soil screening. Soil samples potentially containing glucosinolate-degrading microorganisms were collected from Lamphun province, Thailand. Soil samples were bottled in sterile vials. One gram of each sample was suspended in $10 \mathrm{ml}$ sterile distilled water. After shaking, it was allowed to settle at room temperature for 2-3 hrs. Then, $100 \mu \mathrm{l}$ of supernatant was spread on sinigrin-barium agar plates (Sakorn et al. 2002). Incubation was carried out at $30^{\circ} \mathrm{C}$ and growths were observed daily. Each distinct growing colony was picked and then plated onto nutrient agar plates or potato dextrose agar plates. Re-plating was performed until pure isolate was obtained. Fungal isolates were maintained on potato dextrose agar slants and subcultured monthly. The culture medium used for shaken cultures, modified from Sakorn et al. (1999), was prepared as follows. One hundred grams of brown mustard seed cake (Brassica juncea var. Forge), obtained after fixed-oil expellation, were ground finely by a mortar and defatted with hexane by soxhlet extraction apparatus. The defatted mustard powder was allowed to air-dry and heated at $100^{\circ} \mathrm{C}$ for $30 \mathrm{~min}$, prior to being suspended in boiling water. During this time, it was vigorously stirred and heated 
further for $15 \mathrm{~min}$. The slurry was stirred for additional 3 hrs at room temperature and then filtered. The yellowbrown mustard extract obtained after centrifugation $(10,000$ $\mathrm{x} \mathrm{g}, 20 \mathrm{~min}$ ) was assayed for glucose and glucosinolate contents. Culture medium was prepared by diluting the mustard extract to a final glucosinolate concentration of 10 $\mathrm{mM}$ in $0.1 \mathrm{M}$ potassium phosphate buffer, $\mathrm{pH}$ 6.5. The medium was autoclaved at $121^{\circ} \mathrm{C}$ for $15 \mathrm{~min}$.

\section{Mutation of Aspergillus sp. NR4617 with EMS and MNNG}

The alkylating reagent ethyl methanesulphonate (EMS) was used in a procedure adapted from that of Al-Aidross and Seifert (1980). About $10^{9}$ spores $\mathrm{ml}^{-1}$ of Aspergillus sp. NR4617 were collected from one-week-old slant and 300 $\mu 1$ EMS was added. They were exposed for $30,60,90,120$, 150, 180 and $210 \mathrm{~min}$. The spores of each exposure time were diluted, spread on PDA and incubated for $48-72 \mathrm{hrs}$ at $30^{\circ} \mathrm{C}$. The survival percentage was calculated from the number of colonies obtained at each time interval. The other chemical mutagenesis using MNNG was carried out following the method of Chadha et al. (1999).

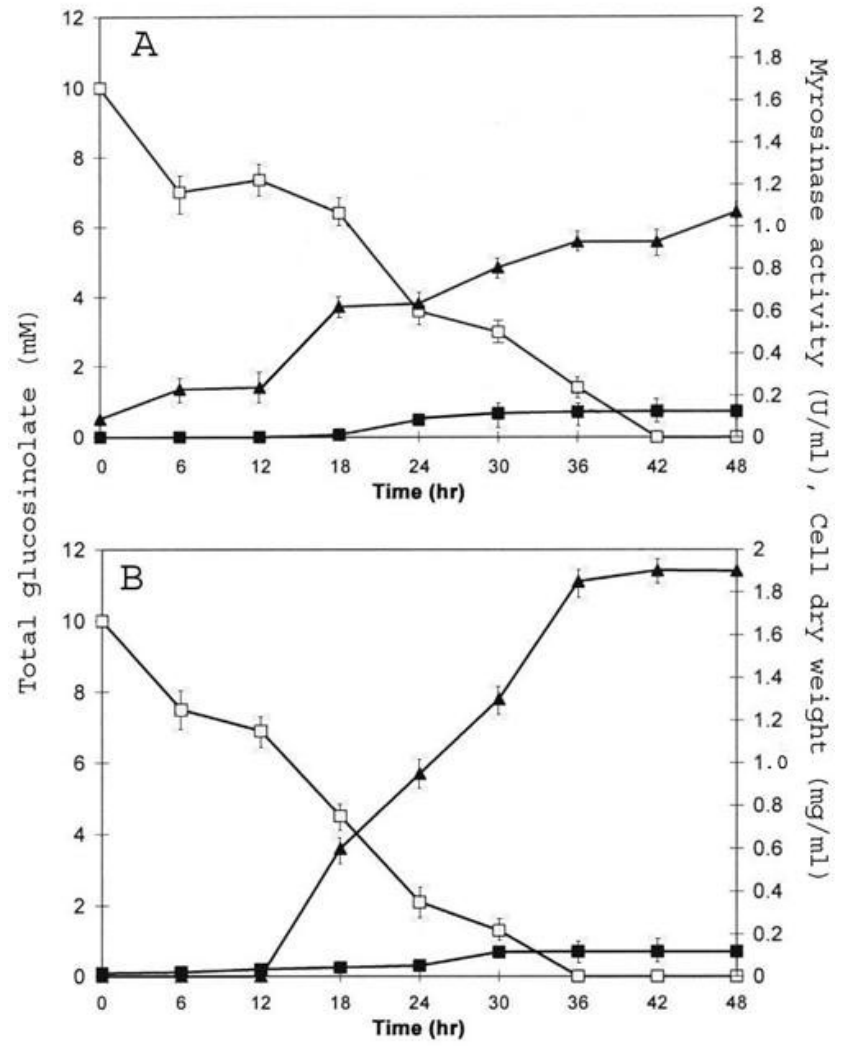

Figure 2. Time course of growth by Aspergillus sp. NR4617 (A) and mutant strain NR4617E1 (B) in shaken flask culture at $\mathrm{pH}$ $6.0,30^{\circ} \mathrm{C}$. Total glucosinolate (口); Myrosinase activity ( $\Delta$ ); Cell dry weight $(\boldsymbol{\square})$. Each value represents means of three replicates test with SD error bars indicated.

\section{Analytical methods}

Myrosinase production by Aspergillus sp. NR4617 and mutants were carried out in mustard extract medium culture with various conditions such as $\mathrm{pH}$, incubation time and incubation temperature. The inoculum was made from 1 week-old culture having a concentration of $10^{6}$ spores $\mathrm{ml}^{-1}$ into 18 Erlenmeyer flasks $(125 \mathrm{ml})$ containing $25 \mathrm{ml}$ mustard extract medium of different $\mathrm{pH}$ values $(10 \mathrm{mM}$ glucosinolates in $0.1 \mathrm{M}$ sodium phosphate buffer). Incubation was carried out at $30^{\circ} \mathrm{C}$ in a water bath, shaken at $150 \mathrm{rev} \mathrm{min}^{-1}$. At each time point, a set of two mycelial samples was harvested and washed. One mycelial sample was determined for fungal cell dry weight by washing and drying it at $105^{\circ} \mathrm{C}$. Culture filtrate of the other sample was assayed for the contents of glucose and glucosinolates while fungal cell pellet was disrupted by a mortar. Cell-free extract obtained after centrifugation $(12000 \mathrm{x} \mathrm{g}, 25 \mathrm{~min}$, $4^{\circ} \mathrm{C}$ ) was assayed for myrosinase activity content. The effect of incubation temperature on myrosinase production was studied at 28 to $40^{\circ} \mathrm{C}$. The myrosinase assay was performed using a spectrophotometer (Sakorn et al. 1999). One $\mathrm{ml}$ of buffer substrate $(33 \mathrm{mM}$ sodium phosphate buffer, pH 7.4 containing $10 \mathrm{mM}$ sinigrin, $3 \mathrm{mM} \mathrm{MgCl}$, 0.55 ATP, $0.72 \mathrm{mM}$ NADP, $3.5 \mathrm{U}$ hexokinase, and $1.75 \mathrm{U}$ glucose-6-phosphate dehydrogenase) was pre-incubated for a sufficient time $(3-10 \mathrm{~min})$ at $30^{\circ} \mathrm{C}$. Then, appropriate amounts of the enzyme were added. After mixing, the reaction was monitored at $346 \mathrm{~nm}$. Myrosinase activity was calculated from absorbance increasing rate, which was due to the formation of NADPH. Protein was determined according to Peterson (1977) using BSA as a standard protein. One unit of myrosinase activity was defined as the amount of enzyme that catalyzed the liberation $1 \mu \mathrm{mol}$ of glucose per min from sinigrin under the condition described above.

Comparisons of enzyme stability between crude extracts of the wild-type and mutant strains were studied. Crude enzyme extracts of the Aspergillus sp. NR4617 and mutants were maintained at $30^{\circ} \mathrm{C}$. At regular intervals of time, myrosinase activity in each sample was determined. The analysis of glucosinolate breakdown products was conducted using a GC analysis, Hewlett-Packard 6890, equipped with a flame ionization detector (FID) and a chrompack column (50 x $0.3 \mathrm{~mm}$ ID), connected to the injector port. The carried gas (helium) was operated at a constant flow rate of $0.5 \mathrm{~cm}^{3} \mathrm{~min}^{-1}$ and a pressure of $50 \mathrm{kPa}$. Temperature of the column was initially maintained at $80^{\circ} \mathrm{C}$ for $6 \mathrm{~min}$ and then programmed to increase at a rate of $10^{\circ} \mathrm{C} \mathrm{min}{ }^{-1}$ for additional $6 \mathrm{~min}$. Temperature of the injector and detector was maintained at 230 and $280^{\circ} \mathrm{C}$ respectively. Samples of standards (normally $1.0 \mathrm{ml}$ ) were extracted with an equal volume of chilled hexane (GC grade). After adding approximately $2 \mathrm{~g}$ of solid ammonium sulphate, capping, shaking and centrifuging (13,000 x g, $15 \mathrm{~min}), 1$ $\mathrm{ml}$ of hexane layer was injected.

Concentrations of any glucosinolate breakdown products in the sample were determined directly from such calibration curve (Sakorn et al. 1999). 


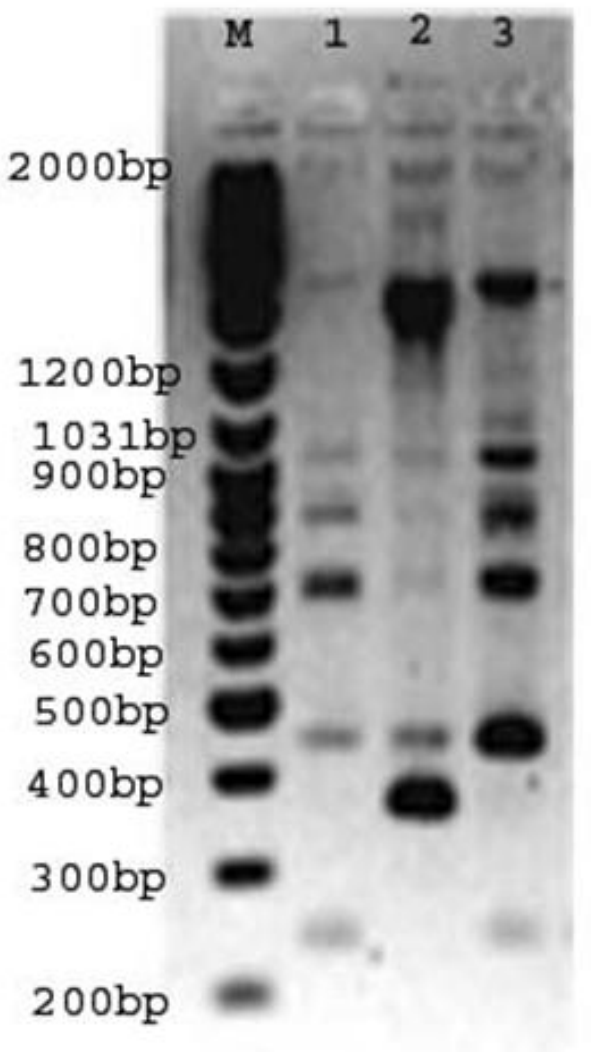

$100 \mathrm{bp}$

Figure 3. Aspergillus sp. NR4617 wild-type strain and 2 chemical mutants RAPD patterns, obtained with the primer OPN13. Commercial molecular weight marker standard was obtained from Fermentas $®(M)$. The next three lanes from left to right contained Aspergillus sp. NR4617 wild-type strain (1), Aspergillus sp. NR4617E1 (2) and Aspergillus sp. NR4617MG3 (3) respectively.

\section{RAPD analysis}

Frozen mycelial were ground with a mortar and pestle to fine powder in liquid nitrogen. Approximately $20 \mathrm{mg}$ of homogenized cell powder was mixed with $600 \mu \mathrm{l}$ of lysis buffer $(100 \mathrm{mM}$ Tris-HCl, $\mathrm{pH} 8.0,100 \mathrm{mM} \mathrm{NaCl}, 20 \mathrm{mM}$ EDTA and $2 \% \mathrm{SDS}$ ) and incubated at $60^{\circ} \mathrm{C}$ for $10 \mathrm{~min}$. The DNA was extracted sequentially with an equal volume of phenol/chloroform (1:1), and chloroform/isoamyl alcohol (24:1). Total nucleic acids were precipitated with 0.7 volume of isopropanol and vacuum dried. Finally, the pellets were re-dissolved in water and treated with RNase A at $37^{\circ} \mathrm{C}$ for $1.5 \mathrm{hr}$ to remove RNA, and the RNase A was inactivated at $60^{\circ} \mathrm{C}$ for $1 \mathrm{hr}$. Final DNA concentrations were determined by measuring with a Model $U$ spectrophotometer (Hitachi, Tokyo, Japan), and the integrity of each DNA sample was examined with an agarose gel electrophoresis.

RAPD was determined according to the procedure of
Pomazi et al. (1994). Ten 10-mer oligonucleotides of the RAPD primer kit $\mathrm{N}$ produced by Operon Technologies Inc. (Alameda, CA, USA) were chosen after preliminary tests for their potential to differentiate these fungi. Nucleotide sequences of the primers were: OPN02 (5'ACCAGGGGCA-3'), OPN04 (5'-GACCGACCCA-3'), OPN05 (5'-ACTGAACGCC-3'), OPN06 (5'GAGACGCACA-3'), OPN07 (5'-CAGCCCAGAG-3'), OPN11 (5'-TCGCCGCAAA-3'), OPN12 (5'CACAGACACC-3'), OPN13 (5'-AGCGTCACTC-3'), OPN14 (5'-TCGTGCGGGT-3') and OPN16 (5'AAGCGACCTG-3'). Amplification was carried out in a Perkin-Elmer Cetus DNA thermal cycler with the following program: initial denaturation at $94^{\circ} \mathrm{C}$ for $4 \mathrm{~min}, 35$ cycles of $1 \mathrm{~min}$ at $94^{\circ} \mathrm{C}, 1 \mathrm{~min}$ at $38^{\circ} \mathrm{C}, 2 \mathrm{~min}$ at $72^{\circ} \mathrm{C}$ and a final incubation at $72^{\circ} \mathrm{C}$ for $7 \mathrm{~min}$. Amplification products were separated by agarose gel electrophoresis and stained with ethidium bromide.

\section{RESULTS AND DISCUSSION}

Approximately 150 soil samples suspected to contain myrosinase-producing microorganisms were collected. The positive strains exhibited opaque zone on sinigrin-barium agar plates. Although growth was observed for several strains, a decrease in the sinigrin content was observed for only eight chosen strains with high activity (data not shown). The highest fungal strains of the eight, Aspergillus sp. NR4617, produced myrosinase only intracellularly was selected for further experiments.

The kinetics of mutagenesis of Aspergillus sp. NR4617 was carried out at different time intervals and Aspergillus sp. NR4617 showed 1\% survival of spores during $150 \mathrm{~min}$ incubation (Figure 1), after which rapid killing of spores was observed and no spores survived at $180 \mathrm{~min}$ of incubation. Four survival spores with myrosinase production from each chemical mutagenesis include NR4617E1-E4 (EMS) and NR4617MG1-MG4 (MNNG).

Chemical mutagenesis gave 8 candidate mutant strains (Table 1). The mutant strains NR4617E1, NR4617E2, NR4617E3, NR4617E4, NR4617MG1, NR4617MG2, NR4617MG3 and NR4617MG4 had activities of 1.902 (171.8\%), $1.425,0.535,1.258$ (113.6\%), 0.989, 0.592, $1.626(148.9 \%)$ and $0.947 \mathrm{U} \mathrm{ml}^{-1}$ respectively. The numbers in parenthesis indicate relative activities to that of wild type strain Aspergillus sp. NR4617. The result was presented that mutant strains (NR4617E1, NR4617E4 and NR4617MG3) produced myrosinase higher than the wildtype. The enhancement of myrosinase activity might be due to structural change of the enzyme, higher amount of the enzyme, increased level of modulator proteins or cofactors promoting the enzyme activity or decreased level of inhibitory proteins.

Strains NR4617E1 and NR4617MG3 grown on mustard extract medium with no supplement gave relatively high myrosinase activity (1.902 and $1.626 \mathrm{U} \mathrm{ml}^{-1}$ respectively) 
compared with those from previous work: Aspergillus syndowi IFO4284, $0.08 \mathrm{U} \mathrm{ml}^{-1}$ (Ohtsuru et al. 1969); Aspergillus niger AKU3302, $0.088 \mathrm{U} \mathrm{ml}^{-1}$ (Ohtsuru and Hata, 1973); Aspergillus syndowi QM31c, $0.096 \mathrm{U} \mathrm{ml}^{-1}$ (Petroski and Kwolek, 1985); and Aspergillus sp.NR-4201, $0.28 \mathrm{U} \mathrm{ml}^{-1}$ (Sakorn et al. 1999). To our knowledge, myrosinase improving chemical mutants characterized by such high levels of enzymatic activities have not been previously reported. The advantages of using Aspergillus sp. NR4617 and its mutants were possession of higher myrosinase activity and ability to grow in the low cost medium.

The growth profile of mutant strains suggested that all the mutants gave similar time course of growth and optimal conditions as the wild-type strain. Figure 2 shows the time course of growth and enzyme activity of Aspergillus sp. NR4617 (A) and mutant strain NR4617E1 (B) cultivated under optimal culturing conditions $\left(30^{\circ} \mathrm{C}, \mathrm{pH} \quad 6.5\right)$. Maximum myrosinase activity of mutant NR4617E1 and NR4617MG3 (data not shown) was reached after $36 \mathrm{hrs}$ of growth. $10 \mathrm{mM}$ glucosinolate was degraded completely in $36 \mathrm{hrs}$ of growth. The growth profiles of NR4617E1 and NR4617MG3 were better than wild-type and from that reported in Aspergillus sp. NR-4201 (Sakorn et al. 1999; Rakariyatham and Sakorn, 2002). The NR-4201 strain degraded 5.5-6.0 $\mathrm{mM}$ of glucosinolate in $48 \mathrm{hrs}$. While mutant strains NR4617E1 and NR4617MG3 degraded 10 $\mathrm{mM}$ glucosinolate in $36 \mathrm{hrs}$ and glucosinolate concentration has decreased rapidly since the beginning of the cultivation.

The stability of enzyme present in the cell free extracts was subsequently determined. Myrosinase from the wild-type Aspergillus sp. NR4617 was inactive after $2 \mathrm{hrs}$ at $30^{\circ} \mathrm{C}$. The stability of the wild-type enzyme was similar to those of enzymes from other microorganisms suggesting myrosinase from microorganisms were not stable at high temperature (Lazzeri et al. 1993). Chemical mutagenesis produced NR4617E1 and NR4617MG3 strains with higher myrosinase production and similar stability. The enzyme from fungal strains NR4617E1, NR4617E4, NR4617MG1, NR4617MG3 and NR4617MG4 lost stability after $60 \mathrm{~min}$ at $30^{\circ} \mathrm{C}$ while those from strains NR4617E2 and NR4617MG2 remained stable for nearly $90 \mathrm{~min}$. Aspergillus sp. NR4617E3 continued to be stable for 60 min. Myrosinase from all mutants reported here remained stable at $4^{\circ} \mathrm{C}$ for 10 days (data not shown). Ohtsuru and Hata (1973) reported that myrosinase from Aspergillus niger AKU3302 had low stability when stored at $5^{\circ} \mathrm{C}$. Sakorn et al. (1999) suggested that myrosinase from Aspergillus sp. NR-4201 was stable for several days at $4^{\circ} \mathrm{C}$.

The product analysis of myrosinase from wild-type Aspergillus sp. NR4617 and all mutant strains revealed that glucosinolate was degraded to allylisothiocyanate (AIT) in neutral conditions, while allylcyanide could not be detected. Glucosinolate degradation rate of wild-type NR4617 and mutant strains, NR4617E1-E4 and
NR4617MG1-MG4 were 0.463, 0.637, 0.592, 0.323, 0.551, $0.457,0.375,0.630$ and $0.418 \mathrm{mM}$ glucosinolate $\mathrm{h}^{-1} \mathrm{mg}$ protein $^{-1}$, respectively (Table 1). The glucosinolate degradation rates of mutant strains (NR4617E1, NR4617E2, NR4617E4 and NR4617MG3) were higher than wild type and correlated with increasing myrosinase activity. The wild-type NR4617 and mutant strains, NR4617E1-E4 and NR4617MG1-MG4, produced AIT at 1.14 (100\%), 2.18 (191.22\%), 1.42 (124.56\%), 0.88 (77.19\%), 1.26 (110.52\%), 1.01 (88.59\%), 0.52 (45.61\%), $1.71(150 \%)$ and $0.95(83.33 \%) \mathrm{ml} \mathrm{kg}^{-1}$ mustard cake respectively (Table 1). The numbers in parenthesis indicate relative production to that of wild type strain Aspergillus sp. NR4617. AIT production was increased in mutant strains NR4617E1, NR4617E2, NR4617E4 and NR4617MG3. These high myrosinase activity offer potential application in AIT production or degradation of glucosinolate in rapeseed and mustard seed for feed industry. Strains NR4617E1 and NR4617MG3 with sufficiently high stability were the strains of choice due to their first and second highest myrosinase production comparing to other mutants at the same culture volume.

To verify that the mutant isolates obtained were not accidental contaminants, their RAPD fingerprints were accessed. This technique was capable to readily distinguish between the 2 isolates (NR4617E1 and NR4617MG3) as the patterns in Figure 3 (OPN13) clearly illustrates. The two isolates yet rooted from NR4617 as they shared some bands. The RAPD patterns were obtained with other selected primers (OPN02, OPN04, OPN05, OPN06, OPN07, OPN11, OPN12, OPN13, OPN14 and OPN16) (data not shown).

In conclusion, an attempt was made to mutate Aspergillus sp. NR4617 to increase myrosinase production. Two of myrosinase production strains (NR4617E1 and NR4617MG3) were identified and NR4617E1 was found to offer better yield of myrosinase with the same stability of the wild-type. Overall results indicated that NR4617E1 mutant can be a potential strain for myrosinase production. Hence, the enzyme from Aspergillus sp. NR4617E1 mutant offers a great potential for industrial applications for example feed detoxification (NR4617E1 has high glucosinolate degradation rate as shown in Figure 2), yield enhancement of flavour production (allylisothiocyanate production) and development for a bioreactor for hydrolyzing large amount of glucosinolates for use as co products of aqueous-enzyme biorefining of cruciferous oilbearing seeds in the future.

\section{ACKNOWLEDGMENTS}

The authors wish to thank Graduated School Chiang Mai University. We also thank the Department of Chemistry, Faculty of Science, Chiang Mai University for chemical support. This research was financially supported by the Thailand Research Fund (TRF). 


\section{REFERENCES}

AL-AIDROSS, K. and SEIFERT, A.M. Polysaccharide and protein degradation, germination, and virulence against mosquitoes in the entomopathogenic fungus Metarhizium anisopliae. Journal of Invertebrate Pathology, July 1980, vol. 36, no. 1, p. 29-34.

BOYDSTON, R.A. and HANG, A. Rapeseed (Brassica napus) green manure crop suppresses weeds in potato (Solanum tuberosum) Weed Technology, OctoberDecember 1995, vol. 9, no. 4, p. 669-675.

BRABBAN, A.D. and EDWARDS, C. The effects of glucosinolates and their hydrolysis products on microbial growth. The Journal of Applied Bacteriology, August 1995, vol. 79, no. 2, p. 171-177.

BROWN, P.D. and MORRA, M.J. Hydrolysis products of glucosinolates in Brassica napus tissues as inhibitors of seed germination. Plant and Soil, April 1996, vol. 181, no. 2, p. 307-316.

CHADHA, B.S.; JASWINDER, K.; RUBINDER, K.; SAINI, H.S. and SINGH, S. Xylanase production by Thermomyces lanuginosus wild and mutant strains. World Journal of Microbiology and Biotechnology, April 1999, vol. 15 , no. 2, p. 217-221.

FENWICK, R.G.; HEANEY, R.K. and MULLIN, W.J. Glucosinolates and their breakdown products in food and food plants. Critical Reviews in Food Science and Nutrition, 1983, vol. 18, no. 2, p. 123-201.

GIL, V. and MACLEOD, A.J. The effects of $\mathrm{pH}$ on glucosinolate degradation by a thioglucoside glucohydrolase preparation. Phytochemistry, 1980, vol. 19, no. 12 , p. $2547-2551$.

GUEYRARD, D.; GRUMEL, V.; LEONI, O.; PALMIERI, S. and ROLLIN, P. Reactivity range of a chiral 1,3oxazolidine-2-thione obtained from vegetable source through chemo-enzymatic processing. Heterocycles, February 2000, vol. 52, no. 2, p. 827-843.

LAZZERI, L.; TACCONI, R. and PALMIERI, S. In vitro activity of some glucosinolates and their reaction products toward a population of the nematode Heterodera schachtii. Journal of Agricultural and Food Chemistry, May 1993, vol. 41, no. 5, p. 825-829.

LEONI, O.; IORI, R.; PALMIERI, S.; ESPOSITO, E.; MENEGATTI, E.; CORTESI, R. and NASTRUZZI, C. Myrosinase-generated isothiocyanate from glucosinolates: isolation, characterization and in vitro antiproliferative studies. Bioorganic and Medicinal Chemistry, September 1997, vol. 5, no. 9, p. 1799-1806.

MAHESHWARI, P.N.; STANLEY, D.W. and GRAY, J.I.
Detoxification of rapeseed production. Journal of Food Protection, 1981, vol. 44, no. 3, p. 459-470.

OHTSURU, M.; TSURUO, I. and HATA, T. Studies of fungous myrosinase. Part I: Production, purification and some characteristics. Agricultural and Biological Chemistry, 1969, vol. 33, no. 9, p. 1309-1314.

OHTSURU, M. and HATA, T. General characteristics of the intracellular myrosinase from Aspergillus niger. Agricultural and Biological Chemistry, 1973, vol. 37, no. 11, p. 2543-2548.

PALOP, H. María de los Llanos; SMITHS, Jan P. and BRINK, Bart Ten. Degradation of sinigrin by Lactobacillus agilis strain R16. International Journal of Food Microbiology, July 1995, vol. 26, no. 2, p. 219-229.

PETERSON, G.L. A simplification of the protein assay method of Lowry et al. which is more generally applicable. Analytical Biochemistry, December 1977, vol. 83, no. 2, p. 346-356.

PETROSKI, Richard J. and KWOLEK, William F. Interactions of a fungal thioglucoside glucohydrolase and cruciferous plant epithiospecifier protein to form 1cyanoepithioalkanes: Implications of an allosteric mechanism. Phytochemistry, February 1985, vol. 24, no. 2, p. 213-216.

POMAZI, A.; WITTNER, A.; PESTI, M. and HORNOK, L. A PCR-generated simple RFLP-probe differentiates three distinct groups within Fusarium oxysporum f. sp. pisi. Acta Phytopathologica et Entomologica Hungarica, 1994, vol. 29, p. 203-213.

RAKARIYATHAM, Nuansri and SAKORN, Prakong. Biodegradation of glucosinolates in brown mustard seed meal (Brassica juncea) by Aspergillus sp. NR-4201 in liquid and solid-state cultures. Biodegradation, December 2002, vol. 13, no. 6, p. 395-399.

RASK, Lars; ANDREASSON, Erik; EKBOM, Barbara; ERIKSSON, Susanna; PONTOPPIDAN, Bo and MEIJER, Johan. Myrosinase gene family evolution and herbivore defense in Brassicaceae. Plant Molecular Biology, January 2000 , vol. 42 , no. 1 , p. 93-114.

SAKORN, Prakong; RAKARIYATHAM, Nuansri; NIAMSUP, Hataichanoke and KOVITAYA, Precha. Sinigrin degradation by Aspergillus sp. NR-4201 in liquid culture. Science Asia, December 1999, vol. 25, no. 4, p. 189-194.

SAKORN, P.; RAKARIYATHAM, N.; NIAMSUP, H. and NONGKUNSARN, P. Rapid detection of myrosinaseproducing fungi: a plate method based on opaque barium sulphate formation. World Journal of Microbiology and Biotechnology, February 2002, vol. 18, no. 1, p. 73-74. 
SMITHS, J.P.; KNOL, W. and BOL, J. Glucosinolate degradation by Aspergillus clavatus and Fusarium oxysporum in liquid and solid-state fermentation. Applied Microbiology and Biotechnology, February 1993, vol. 38, no. 5, p. 696-701.

XUE, Jiaping P.; LENMAN, Marit; FALK, Anders and RASK, Lars. The glucosinolate- degrading enzyme myrosinase in Brassicaceae is encoded by a gene family. Plant Molecular Biology, January 1992, vol. 18, no. 2, p. 387-398.

YENISH, J.P.; WORSHAM, A.D. and YORK, A.C. Cover crops for herbicide replacement in no- tillage corn (Zea mays). Weed Technology, October-December 1996, vol. 10, no. 4, p. 815-821. 